И.А. ЧИТАО, А.А. ХАТХЕ, З.С. ХАБЕКИРОВА, А.А. КАЛАШАОВА

\title{
ENGLISH
}

\section{ON ECONOMICS}

Методические указания

nо работе с экономическими текстами

на английском языке

(для студентов экономических специальностей)

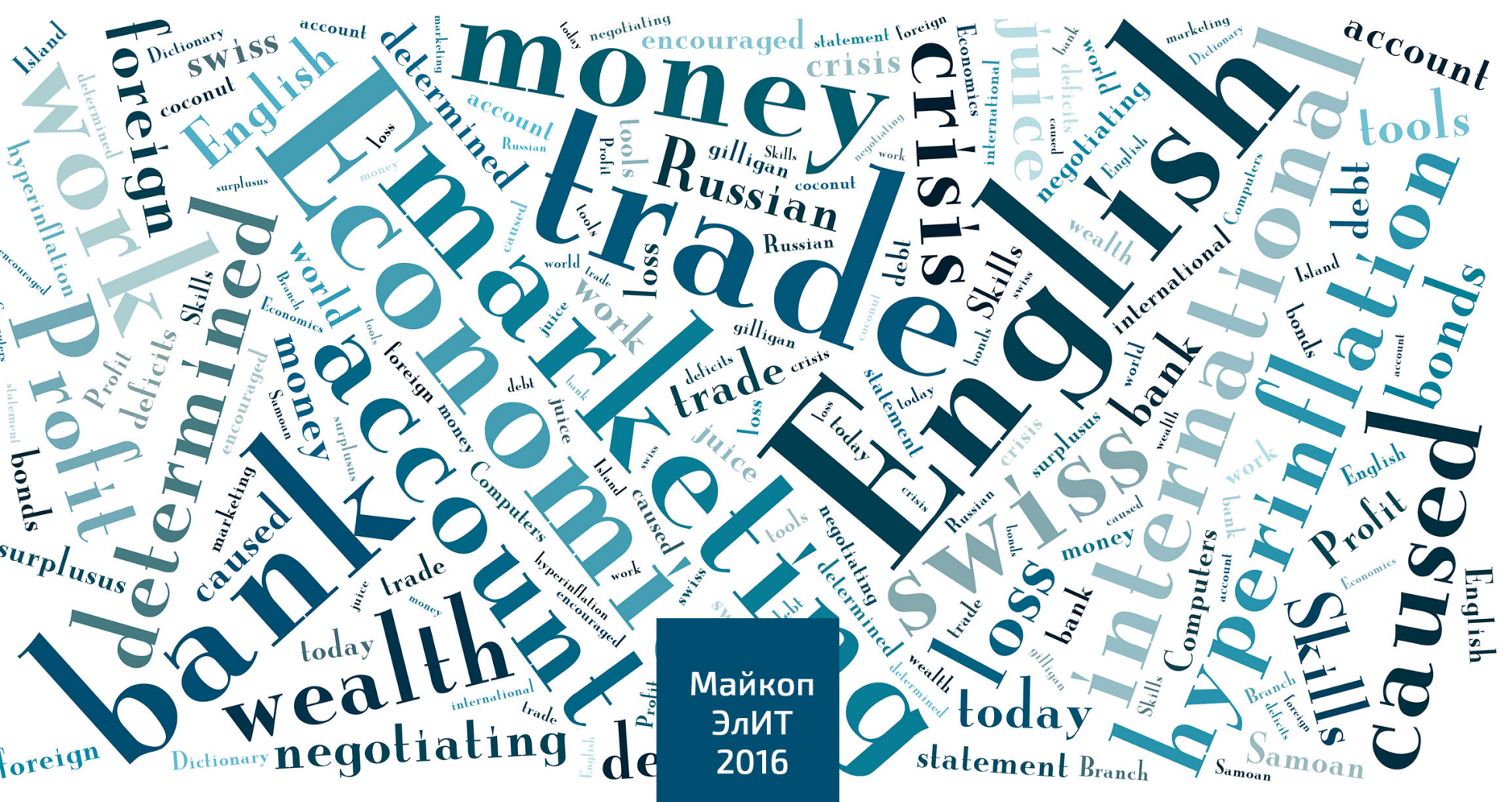


Читао, И.А.

English on Economics: Методические указания по работе с экономическими текстами на английском языке (для студентов экономических специальностей). [Электронный ресурс]: учебное электронное издание И.А. Читао, А.А. Хатхе, 3.С. Хабекирова, А.А. Калашаова - Электрон. дан. (1,9 Мб). - Майкоп: ЭлИТ, 2016. - 1 электрон. опт. диск (CD-R).

\section{Публикуется по решению редакционно-издательского Совета университета и кафедры иностранных языков}

\section{РЕЦЕНЗЕНТЫ:}

Таранова Л.А. - кандидат педагогических наук, доцент, почетный работник высшего профессионального образования

Паранук Л.Г. - кандидат философских наук, профессор

Лоова А.Д. - кандидат филологических наук, доцент

В методических указаниях представлены тексты информативного характера, ориентированные на формирование навыка полного извлечения информации из прочитанного. В процессе чтения, обучаемые смогут освоить необходимую лексику, представленную после каждого текста, а также ответить на вопросы, построенные на их материале.

Методические указания представляют интерес для широкого круга лиц, желающих совершенствовать деловой английский язык.

ББК 81.432.1-923

УдК $802.0(075)$

(c) Адыгейский государственный университет, 2016

() И.А. Читао, А.А. Хатхе, З.С. Хабекирова, А.А. Калашаова, 2016

(C) Оформление электронного издания ООО «ЭлИТ», 2016 


\section{ОГЛАВЛЕНИЕ}

ПРЕДИСЛОВИЕ. 4

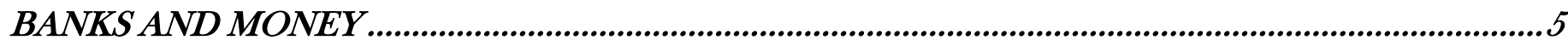

HOW DOES A SWISS BANK ACCOUNT WORK ? ...............................................................

WHAT CAUSED THE INTERNATIONAL DEBT CRISISP ............................................................10

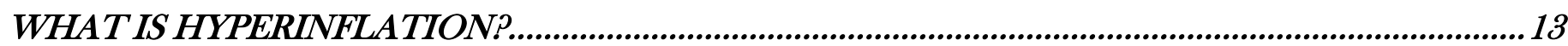

HOW IS WEALTH DETERMINED AROUND THE WORLD?.................................................16

PROFIT AND LOSS STATEMENT GILLIGAN'S COCONUTJUICE LTD. (SAMOAN ISLAND

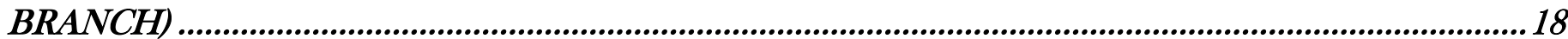

HOW IS FOREIGN TRADE ENCOURAGED? …..................................................................21

WHAT ARE TRADE SURPLUSUS AND DEFICITS ${ }^{\circ}$...................................................................24

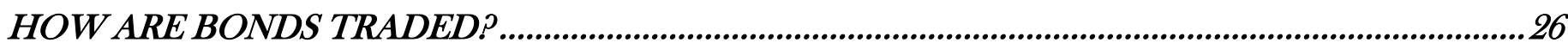

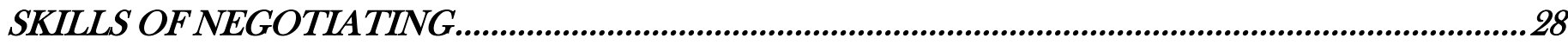

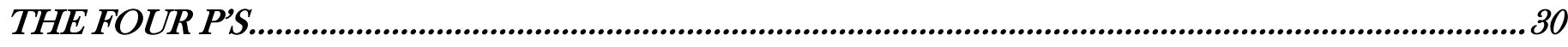

MARKETING TODAY

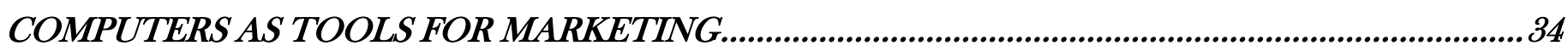

ENGLISH-RUSSLAN DICTIONARY OF ECONOMIC AND BUSINESS TERMS ................................36

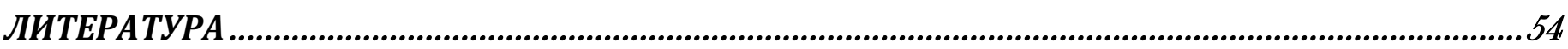




\section{ПРЕДИСЛОВИЕ}

Предлагаемые методические указания по английскому языку предназначены для студентов экономического факультета.

В методических указаниях представлены тексты информативного характера, ориентированные на формирование навыка полного извлечения информации из прочитанного. В процессе чтения обучаемые смогут освоить необходимую лексику, представленную после каждого текста, а также ответить на вопросы, построенные на их материале.

Для облегчения работы с текстами в конце пособия приводится краткий терминологический словарь по экономике.

Поскольку в данных указаниях представлены темы, построенные на реальных ситуациях, такие как банки, деньги, инфляция, маркетинг, бухгалтерский учет и т.д., они могут быть использованы специалистами, работающими в области бизнеса и коммерции, в финансовых компаниях и биржах. Материал указаний представляет интерес для широкого круга лиц, желающих совершенствовать деловой английский язык. 


\section{BANKS AND MONEY}

For a full view of bank and money the city to visit is Amsterdam. It is associated with not one but two of the great developments in their history.

In 1609, money - hard, coined money - was, as money goes, abundant in Amsterdam. Everywhere in Europe men were taking the coins and sweating and clipping them, thereby getting metal to make more of them. It was to the problem of quality that, the merchants of Amsterdam now addressed themselves. They created a bank owned by the city; the bank solved the problem of the quality of the coins by going back to the system that antedated the invention of coinage. That was weighing. A merchant brought his good and wretched coins to the bank, the bank weighed them, and the weight of the pure metal was then credited to his account. This deposit was a highly reliable form of money. A merchant could transfer in to the account of another merchant. The recipient knew that he was getting honest weight, nothing funny. Payments through the bank commanded a premium.

Then came the second Amsterdam discovery. The deposits so created did not need to be left idle in the bank. They could be lent. The bank then got interest. The borrower then had a deposit that he could spend. But the original deposit still stood to the credit of the original depositor. That too could be spent. Money spendable money had been created.

The important thing, obviously, is that the original depositor and the borrower must never come at the same time for their deposits: - their money. As will now be evident - very monetary innovation or reform carries the seeds some new abuse. So it was here. One of the important borrowers from the Bank was the Dutch East India Company. The members of the Company were often the same men who ran the Bank. In the eighteenth century the India Company fell on hard times; there was war with England, ships did not come back. It was slow pay at first, and then its loans went into default. Early in the last century suspicion spread, the weakness was affirmed, the depositors started coming, and they couldn't be paid. 


\section{WORDS}

money

hard money

coined money

to be abundant

to take coins

to sweat coins

to clip coins

to antedate

coinage

weighing

merchant

good coin

wretched coin

to credit to one's account

deposit

to transfer money to the account of ...

recipient

payment(s)

premium

to command a premium

idle money

to lend

borrower

to stand to the credit of the original depositor

to create money

monetary

abuse

loan деньги

металлические деньги; твердая валюта

деньги в форме монеты

иметься в изобилии

обрабатывать монеты

стирать золото с монет

обрезать края у монет

предшествовать

1. металлические деньги;

2. чеканка монет

взвешивание

купец, торговец

полноценная монета

неполноценная монета

заносить на чей-либо счет

депозит, вклад, взнос

перевести деньги на чей-либо счет

получатель

платеж (и)

премия, оплата за услуги

давать премию, оплачивать услуги

бездействующие, неиспользуемые деньги (сокровище)

ссужать, давать взаймы

заемщик, получатель ссуды

быть записанным на первоначального вкладчика

создавать деньги

денежный, кредитно-денежный; валютный (фонд)

злоупотребление

заем, ссуда 
default

to go into default

Amsterdam неуплата, прекращение платежей

прекращать платежи

Амстердам

1. as money goes - исходя из того, как деньги обращаются.

2. nothing funny - здесь никакого обмана, без обмана.

3. It was slow pay at first, and then its loans went into default. - Сначала уменьшились вклады, а затем прекратились банковские займы.

\section{Find the answers to the following questions in the text}

1. What role did Amsterdam play in the economic life of European at the beginning of the $17^{\text {th }}$ century? Was it the greatest merchant city then? Why did its role decline?

2. What was typical of coined money circulation in European countries at the beginning of the $17^{\text {th }}$ century? What did men do to get more metal to make money?

3. Why did coins lose weight and purity and become deficient? How was the problem of quality of coins solved by the Bank of Amsterdam?

4. How were deposits created? What did the bank do with idle money? What do you think was necessary for a normal money circulation when banking was just developing? Why couldn't the original depositor and the borrower do their transaction simultaneously? 


\section{HOW DOES A SWISS BANK ACCOUNT WORK?}

Switzerland is one of the few countries in the world that guarantees, by law, the secrecy of its bank accounts. As long as the client of a Swiss bank has not done anything that is considered illegal in Switzerland, the bank will not reveal the client's identity to anyone.

During World War II, for example, many families from war-torn Germany, Italy, and France were able to keep their savings secure by putting them in Swiss banks. Many Europeans still consider having a bank account in Zurich, Basel, Lugano, or Geneva to be a sign of financial security.

Opening a legal, numbered Swiss bank account is still relatively easy to do, usually involving nothing more than going to Switzerland, Filling out a few forms, and making a deposit. Swiss bankers are known to be dependable, trustworthy, and, above all, discreet. These qualities have made Switzerland one of the world's banking centers. But they have also made Switzerland a center for money laundering.

Swiss bank accounts are useful for money-laundering schemes because once passes through a respectable Swiss bank, it is accepted anywhere in the world. When several Swiss banks were found to be facilitating the activities of international drug traffickers in the 1980s, the Swiss authorities finally decided to break open several secret accounts that were linked to illegal activities abroad.

Most people holding Swiss bank accounts, however, do not use them to launder illegally earned money. They merely want their legally earned funds to be safe and free from government control and taxes at home. Swiss bankers do not reveal the accounts of clients accused of avoiding taxes in their home country, since tax evasion is not considered to be «illegal» in Switzerland: it is only a civil, not a criminal offense.

Foreigners - as long as they break no Swiss laws - can keep their money in Swiss bank accounts without fear. This guarantee of secrecy can be used by many unscrupulous people for 
a wide variety of shady international activities. In the case of the Iran-contra scandals during the 1980s, for example, the secret deals between America's CIA and the Iranian arms merchants were paid for in part with money deposited by CIA agents at banks in Switzerland.

Philippine dictator Ferdinand Marcos had also deposited large sums of illegally acquired funds in Swiss banks during the 1970s and 1980s. When he was deposed, the Philippine government called for the return of these funds, which was agreed to by the Swiss authorities. After several abuses of Swiss banking secrecy, the Swiss authorities announced that they would be ready to open any accounts revealed to be linked to illegal international activity.

\section{WORDS}

$\begin{array}{ll}\text { accuse } & \text { обвинять } \\ \text { avoid } & \text { избегать, уклоняться } \\ \text { civil } & \text { гражданский, штатский } \\ \text { shady } & \text { сомнительный, темный } \\ \text { case } & \text { случай, дело (судебное) } \\ \text { deal } & \text { сделка, дело }\end{array}$

\section{Find the answers to the following questions in the text:}

1. Does Switzerland guarantee the secrtrecy of its bank accounts? When does if reveal the client's identity to anyone?

2. What do Europeans consider to be a sign of financial security?

3. What has made Switzerland a center for money laundering?

4. When did Swiss authorities finally decide to break open several secret accounts that were linked to illegal activities abroad?

5. What is the purpose of the most people in holding Swiss bank, accounts?

6. How long can the foreigners keep their money in Swiss bank?

7. What can you tell of illegal activity of Philippine dictator Ferdinand Marcos. 


\section{WHAT CAUSED THE INTERNATIONAL DEBT CRISIS?}

If you owe the bank a small amount of money and you can't pay it, then you are in trouble. However, if you owe the bank an enormous amount of money and you can't pay it, then the bank is in trouble.

By the end of the 1980s, European and American banks that had made large loans to the Third World were in big trouble. Countries such as Argentina, Brazil, and Mexico just could not pay the money back. In many cases, the debtor countries could not even afford to pay the interested on their interest on their outstanding loans. And some of the American creditor banks did not have enough capital and reserves to cover these nonperforming loans.

The developing countries had gambled in the 1970s and borrowed billions of dollars from Japanese and Western banks, hoping to grow their way out of poverty. But the gamble Failed. By the 1980s, the debtor countries of the Third World found themselves confronted with the scissors effect of soaring interest rates and an economic slump in the developed countries, reducing worldwide demand and lowering inflation. The prices of commodities such as coffee and sugar fell sharply, reducing many developing countries» export earnings. Debtor countries were forced to borrow even more money to pay for the increased cost of oil and debt payments.

Although some of the original loans had been used to line the pockets of government officials and businessmen, mush of the money was actually spent on valuable infrastructure projects like electricity system and roads. But the tragedy of the (debt crisis is that the majority of the Third World's debt was generated on the back of the debt itself. The high interest payments of the 1980s, largely caused by the U.S. Federal Reserve's battle against inflation, had to be paid for with increased borrowing as the debtor countries of Third World refused to admit that their gamble was failing.

Brazil, for example, had managed to keep its economy alive during the 1980s despite the huge interest payments it had to make to service its debt. It exported a wide range of goods, ranging from coffee and airplanes to tanks and shoes, racking up annual trade surpluses of ten 
to twenty billion U.S. dollars, the third highest trade surplus in the world after Japan and West Germany. But most of these earnings were sent abroad just to pay the interest on more than $\$$ 100 billion of debt, the highest in the developing world. Funds were being transferred abroad instead of invested into the weakening Brazilian economy.

Faced with the impossibility of more foreign loans, the Brazilian government was forced to start looking for funds within the country. This was done by issuing domestic debt, usually in the form of government bonds. In order to attract buyers for its bonds within Brazil, the government had to pay high interest rates, sometimes several percent-age points higher than the inflation rate. For example, with local inflation at 20 percent per year, the government would pay 25 percent interest on its bonds, for a «real» interest rate of 5 percent.

Eventually, the Brazilian government was forced to issue even more debt to pay for its increased interest payments. Internal debt soared, because not enough taxes were being collected to pay for the increased government spending.

By borrowing more money on the back of the original loans, the debt problem was only getting worse. But neither the banks nor the Third World debtor countries wanted to admit that there was just no money available. Not only were the debtor countries unable to pay back the principal - the original amount borrowed - in many cases they were not even able to keep up with the interest payments. The principal and interest payments on the loans had built up like a snowball rolling downhill, and the borrowers and the banks of the world found themselves in trouble, (from «A beginner's guide to the world economy» by Randy Charles Epping).

\section{WORDS}

amount

available

borrow

bond

$d e b t$

domestic debt

enormous

creditor

inflation

loans сумма

наличный

занимать

облигации

долг

внутренний долг

громадный

кредитор

инфляция

займы 
owe

pay

payment

poverty

unable to pay быть должным

платить

платёж

бедность

неспособность платить

\section{Find the answers to the following questions in the text:}

1. What is the reason of bank's and client's troubles?

2. Why were European and American banks in big trouble by the end of the 1980s.?

3. What did the developing countries do in the 1970s in order to grow their way out of poverty?

4. What was the tragedy of the debts crisis?

5. How had Brazil managed to keep its economy during the 1980s? 


\section{WHAT IS HYPERINFLATION?}

During a period of hyperinflation in Argentina, when the currency was losing its value at an alarming rate, it was joked that it was paid for at the beginning, when the currency was still worth something, while the taxi ride was paid for at the end after the currency had already lost its value.

Hyperinflation - an explosions in the prices of goods and services - is a symptom of an economy out of control. Hyperinflation has occurred all over the world: in Germany between the two world wars, and later in Israel and parts of Eastern Europe. But it has been most widespread in the debtor countries of Latin America, where it resulted primarily from government policies that attempt to satisfy political demands without increasing taxes.

When a profligate government finances spending by increased borrowing or by simply printing new currency, prices will increase as the new money enters the economy. The expectation of runaway inflation fuels the fires of hyperinflation. Eventually this wage and price spiral takes on a life of its own: price rise, leading to a demand for increased wager, which results in higher prices. Imagine buying goods for a home or factory, or playing The Price is Right, when prices are increasing 200 percent a month. Even winning the lottery may not help when a million or a billion pesos does not even pay for next month's rent.

The rising prices of hyperinflation end up hurting the poor people most, because their day - today expenses consume a significantly higher percentage of their total income. Some countries try to index salaries and social service payments to keep up with inflation, but salaries and social payments rarely keep pace with the increase in prices, and purchasing power declines. Even though a salary is increased in nominal terms, what the salary will actually buy - its real value can decline. Hyperinflation especially hurts those on fixed incomes such as old-age pensions: when there are no cost-of-living increases, stipends can become virtually worthless.

Governments often refuse to take tough economic action against hyperinflation because they fear the political consequences of austerity plans or increased taxes. In order to keep large state work forces satisfied, for example, governments borrow money to keep from closing inefficient 
state industries or reduce bloated bureaucracies. Overburdened governments usually keep the economy going by increasing the money supply even further, issuing more government debt or printing ever more money. As the government loses control of the economy, the vicious circle of wage and price increases spins out of control.

\section{WORDS}

$\begin{array}{ll}\text { hyperinflation } & \text { гиперинфляция } \\ \text { eventually } & \text { в конце концов } \\ \text { currency } & \text { валюта } \\ \text { wage } & \text { заработная плата } \\ \text { value } & \text { стоимость } \\ \text { spiral } & \text { ускоряющееся повышение или падение } \\ \text { alarmingrate } & \text { тревожный темп } \\ \text { pesos } & \text { песо (латиноамериканская денежная единица) } \\ \text { cheap } & \text { дешевый } \\ \text { rent } & \text { арендная плата } \\ \text { explosion } & \text { взрыв } \\ \text { expenses } & \text { расходы } \\ \text { occur } & \text { случаться, иметь место } \\ \text { consume } & \text { потреблять } \\ \text { widespread } & \text { шignificantly } \\ \text { debtor } & \text { широко распространяться } \\ & \text { дуественно } \\ & \text { доник }\end{array}$

percentage процент, процентное отношение, содержание, часть, доля

primarily первично, первоначально

total income полный доход

attempt попытки

to index salaries показать оклад

satisfy удовлетворять, утолять

purchasing рассрочка

demands спрос

declines отклонять 
increasing taxes

tough

profligate

consequences

borrowing

vicious

expectation

inefficient

fuels

bureaucracies увеличенные налоги

жесткий

расточительный

последствие

заимствование

порочный, злобный

ожидание

неспособный, неэффективный

топливо

бюрократия, бюрократизм

\section{Find the answers to the following questions in the text}

1. Why was it cheaper in to the take a taxi a bus?

2. What is hyperinflation? Where has it occurred?

3. Does the printing new currency help to prevent hyperinflation?

4. Whom does hyperinflation hurt especially?

5. What do the governments do in order to keep large state work forces satisfied? 


\section{HOW IS WEALTH DETERMINED AROUND THE WORLD?}

A nation's wealth can best be determined by looking at its people. But it is difficult to rely on any one statistic. Are the Kuwaitis better off because they earn more money per capita then the Brazilians? Are the French better off if they have more telephones per household then the Japanese? Are Italians better off because they save more money then the Canadians?

There are many different ways to determine wealth. Economists define wealth as what a person owns, such as stocks and real estate, but many people look first to their level of income to see if they are well off. Comparing salaries in different countries, however, is like comparing apples and oranges, because the salaries in each country are paid in different currencies. We need to somehow translate what each person earns into a common unit of measure.

One way of translating salaries is to first compare the value of the currencies of the countries in question. This is usually done by using exchange rates that tell us the value of one currency calculated in terms of another.

Exchange rates, determined by the foreign exchange markets around the world reflect the markets" view of each country's economic and political situation. By using exchange rates, a salary in yen in Tokyo can be converted into U.S. dollars to make it comparable to a salary in Los Angeles. Or it can be converted into French francs to make it comparable to a salary in Paris.

Because the cost of living varies widely from one country to another, however, it is difficult to translate salaries by simply using currency exchange rates. If a Big Mac or an apartment costs three times as much in Tokyo as in Los Angeles or Paris, a higher salary in Japan does not necessarily mean a Japanese worker is better off than an American or French worker.

It is sometimes more valuable to look at what salaries will actually buy in each country, A salary's «purchasing power» tell us how many goods and services it can actually buy. Comparing the cost of group of goods and services from country to country, therefore, gives us a more reliable exchange rate, called purchasing power parity (PPP). The PPP exchange rate is 
calculated by looking at the cost of groceries and other items such as vacation trips, automobiles, insurance, and rent in different countries.

By choosing this basket of goods and services and calculating their cost in different countries around the world, we can compare the purchasing power of «real» value of salaries from country of country. Although one country may be richer in terms of amount of money each citizen owns or earns, what counts in the long run is what each person can do with this wealth.

\section{WORDS}

$\begin{array}{ll}\text { define } & \text { определять, устраивать } \\ \text { income } & \text { доход } \\ \text { salaries } & \text { зарплата, оклад } \\ \text { currency } & \text { деньги } \\ \text { measure } & \text { мера, размер } \\ \text { value } & \text { стоимость, ценность } \\ \text { rate } & \text { норма, расценка } \\ \text { valuable } & \text { ценный } \\ \text { groceries } & \text { бакалейный } \\ \text { insure } & \text { страхование }\end{array}$

\section{Find the answers to the following questions in the text}

1. What can be determined nation wealth by?

2. There are different ways to determine wealth, aren't they? What are they?

3. What is the first way of translating salaries?

4. What for can a salary in jen in Tokyo be converted in?

5. Does a higher salary means that a Japanese worker is better than an American or French ones?

6. What does a salary's «purchasing power» tell us about?

7. Can we compare the purchasing power or «real» value of salaries from country to country? 


\title{
PROFIT AND LOSS STATEMENT GILLIGAN'S COCONUT JUICE LTD. (SAMOAN ISLAND BRANCH)
}

\author{
Period : one year
}

Revenues (from sale of coconut juice): $\quad \$ 50$

Cost of Goods Sold (paid to coconut pickers): $\$ 10$

Other Expenses ( advertising on beach): $\quad \$ 10$

Gross Profit: $\quad \$ 30$

Taxes (33\% rate): $\quad \$ 10$

Net Profit: $\quad \$ 20$

Any enterprise from a major multinational corporation to a coconut juice stand in the South Pacific need a summary of everything the company has earned and spent over a given period of time. This overview of company's day-to-day activities is called an income statement or a profit and loss statement (P\&L).

A company making and selling coconut juice on a South Pacific beach would start its P\&L with a summary of all revenues from selling its product. To determine its profit, the company needs to subtract its expenses from its revenues. First, it would subtract the costs incurred in producing the juice, called «cost of goods sold». Expenses such as salaries or maintenance of assets would also have to be accounted for. Other expenses, such as interest on loans, would then have to be deducted.

Finally, depreciation, the decline in value of fixed assets, such as machinery and tools, would have to be deducted from earnings. Deprecation causes numerous accounting nightmares because there is no way to determine how much a fixed asset really declines in value over time. Many companies take advantage of this uncertainty to show as much «loss» as possible as soon as possible, reducing earnings in order to pay less tax in the early years of the asset's life. By delaying tax payments, companies can earn valuable interest on their retained earnings.

Once all expenses have been deducted from the revenues, a company can see its total profit 
or loss. This is the proverbial bottom line. It tells us how much the company's assets and liabilities changed over the course of the year.

Another tool for understating a company's activity is to look at its cash flow. This measures the actual flow of funds - real money - flowing into and out of a company during a given period of time. A company's cash flow, or "cash summary», factors out all of the accounting tricks and looks at what a company really earned. Even though it does not tell us the company's «profit», cash flow sometimes gives a clearer picture of a company's true earnings, because it excludes accounting tools such as depreciation.

Cash flows and profit and loss statements are essential for understanding the revenues, expenses and profits of any organisation, including nonprofit organisations such as the World Wildlife Fund or the United Nations. Even if pro fits are not distributed to shareholders, any organisation need a $\mathbf{P} \& \mathbf{L}$ to account for its activities to see whether it is being efficiently and honestly run.

\section{WORDS}

multinational corporation depreciation

pro fit and loss statement proverbial bottom line cash flow

liability

deduct

revenue

statement

cost

expenses многонациональное объединение обесценивание, снижение стоимости официальный отчет о прибылях и убытках общеизвестный оптимальный

прием кассовый поток ответственность вычитать, удерживать годовой доход официальный отчет цена расходы

\section{Find the answers to the following questions in the text}

1. What is called a profit and loss statement?

2. What must the company do in order to determine its profit?

3. Why do tire companies try to reduce earnings in the early years of the asset's life? 
4. What gives a clearer picture of a company's true earnings?

5. Are cash flows and profit and loss statements essential for understanding the revenues expenses and profits of any organisation? 


\section{HOW IS FOREIGN TRADE ENCOURAGED?}

When every country is allowed to do what it does best - letting the French excel is fashion, on the Japanese in electronics, and the American in aircraft, for example - the world economy prospers. With free trade, whoever produces the best product at the best price can sell these products around the world, benefiting consumers everywhere.

By encouraging foreign trade, countries expose their own producers to foreign competition, which can be disastrous for many poorly managed companies. This can lead to short - term layoffs and idle factories. In the long run, however, foreign competition usually forces companies to be more efficient and more competitive, helping the country to become a successful and profitable member of the global economy.

Free trade is based on the notion of open markets. With a level playing field, companies is one country can compete openly with companies of other countries to sell their goods in foreign markets.

When a government wants to encourage a new trading partner, it removes restrictions and barriers to its internal market. This courtesy, called most favoured nation status in the United States, in provided to countries whose political and economic policies are seen to merit favoured status. Countries may also encourage trade by allowing importers and exporters to barter goods. For example, in order to overcome a temporary scarcity of hard currencies in the Soviet Union, Pepsi-Cola traded soft drinks for vodka, which was then sold for dollars, yen, or marks in the West.

When a country wants to encourage its own exports, it can provide incentives to make the products more competitive on the world market. Some countries provide loans or grants to foreign buyers of a country's goods and services through state-supported export-import banks. These «ex-im» banks provide low-cost loans-called export credits - that help stimulate exports. These loans are sometimes criticised for going too far, encouraging exports at the expense of producers in other countries. 
At times, countries might want to encourage imports of foreign goods and services to decrease international tensions resulting from trade imbalances. When Germany and Japan were criticised for running large trade surpluses in the 1980s, for example, they undertook measures called «external adjustment» to increase their imports. One way to encourage imports is to increase the value of a country's currency, making foreign goods and services less expensive then locally-made product.

Another way to encourage imports is to give the economy a shot in the arm by lowering interest rates, stimulating purchases at home and abroad. This cheaper money usually means more sales of goods such as televisions and automobiles. In countries such as Germany, where money consumer goods are imported, lowering the interest rates can encourage imports of everything from Vietnamese rice to Canadian sporting goods.

Another way to encourage imports would be to reduce cultural barriers that may limit purchases of foreign products. For example, the Japanese government undertook a program in the 1980s to convince Japanese consumers to buy more foreign products (such as U.S. beef) in an effort to ease the threat of retaliatory trade sanctions from its unhappy trading partners.

\section{WORDS}

foreign trade

free trade

to expose

idle factories

to be disastrous

foreign competition

remove restrictions

internal market

temporary scarcity

hard currency

external adjustment

purchase

cheaper money

trading partners иностранная торговля

свободная торговля

выставлять

бесполезные фабрики

быть гибельным

иностранная конкуренция

удалять препятствия

внутренний рынок

временный недостаток

обесцененная валюта

внешние поправки

покупка

обесцененные деньги

торговые партнеры 


\section{Find the answers to the following questions in the text}

1. When does world economy prosper?

2. What helps the country to become a successful and profitable member of global economy?

3. What are open markets?

4. What does a government do in order to encourage a new trading partner?

5. How does the country encourage its own experts?

6. What can you say about imports of foreign goods and services encourage? 


\section{WHAT ARE TRADE SURPLUSUS AND DEFICITS?}

Just like any business, a country has to keep track of its inflow and outflow of goods, services, and payments. At the end of any given period, each country has to look at its «bottom line» and add up its international trade and investments in one way or another.

The narrowest measure of a country's trade, the merchandise trade balance, looks only at «visible» goods such as videocassette recorders, wine, and motorcycles. Trade in visible goods is commonly referred to as the trade balance even though it includes only those tangible goods that can actually be loaded on a ship, airplane, or whatever other means of transports to move goods from one country to another.

The current account is a better measure of trade, because it includes a country's exports of services, in addition to its visible trade. It may not be obvious, but many countries make a lot of money exporting «invisibles» such as banking, accounting, and tourism. A tourist abroad, for example, «buys» hotel and restaurant services in the same way as a consumer at home would buy an imported appliance. Movies and banking services have to be paid for just like bags of rice.

The current account tells us which countries have been profitable traders, running a current account surplus with money in the bank at the end of the year, and which countries have been unprofitable traders, having imported more than they've exported more than they've exported, running a current account deficit, or spending more than they've earned.

Trade deficits and surpluses are balanced by payments that make up the difference. A country' with a current account surplus, for example, can use the extra money to invest abroad, or it can put it in its cookie jar of foreign currency reserves. A country running a current account deficit has to look abroad for loans or investments, or be forced to dip into its own reserves to pay for its excessive imports. All of these payments and transfers of funds are added up in a country's capital account.

The widest measure of a country's trade is called its balance of payments. It includes not 
only payments abroad, but the goods, services, and all transfers of funds that cross international borders. The balance of payments adds up everything in a country's current account and capital account. Since all the trade in goods and services is «balanced» by the international transfers of funds, the balance of payments should add up to zero at the end of accounting period. Every banana, every automobile, every investment and payment that crosses a country's borders gets included in this final of international trade and investment - the balance of payments.

\section{WORDS}

trade surpluses

inflow and outflow

merchandise trade balance

visible

current account

appliance

profitable торговые излишки

приток и утечка

коммерческий баланс

видимый

текущий счет

приспособление, прибор

прибыльный

\section{Find the answers to the following questions in the text}

1. What track of goods, services and payments has a country to keep?

2. What tangible goods does the trade balance include?

3. Why is the current account a better measure of trade?

4. What does the current account tell us?

5. What payments and transfers of funds are added up in a country's capital account?

6. What is the widest measure of a country's trade? 


\section{HOW ARE BONDS TRADED?}

Bonds are traded around the world twenty-fours a day, usually in trading rooms of banks and securities houses that are connected by an elaborate system of electronic communications foment. The largest international capital markets are based in London, New York, and Tokyo, but bonds are traded in almost every official center in the world, from Paris to Bangkok, from Abu Dhabi Vancouver.

Since it is difficult for bond investors to find individual buyers and sellers, they usually go to professional «market-makers» who buy and sell their bonds for them. Although some bond trading takes place on public trading floors like stock exchanges, most of the world's fixedincome securities, or bonds, are traded by banks and securities houses acting as market-makers of behalf of their clients.

Bond markets are just like any other competitive market in that traders make money by buying for less and selling for more. To buy or set a bond, an investor goes to a trader who makes a «market» with two prices: a «bid» prices and an «offer» price. A trader makes money by buying bonds at the lower bid price and by selling them at the higher office. The difference between the two prices is called the spread.

Bond traders are forced by the market to keep their prices and spreads competitive. Some markets are so competitive that the bid and offer prices are quoted in fractions of a percent, sometimes given as $1 / 32$ nds.

Bonds are usually traded with priced on a percentage of their original face value. When the price of a thousand-dollar bond rises by ${ }^{16} / 32$, or one half of one percent, its value rises by five dollars. Since the original value of the bond and its interest rates do not change, adjusting the bond's price it a new yield. Bond yield calculations are so complex that most traders use calculators to detennine which prices bring a bond's interest rate in line with changing market.

In the international capital markets, some bonds, such as U.S. Treasury bonds, serve as bellwether indicators of the market as a whole. Because of the enormous amount of U.S. 
Treasury debt issued, international investors prefer to use this market for a large part of their trading and investing. U.S. government securities are said to be the most liquid bonds in the world because they can be traded internationally in large quantities at almost any given time.

\section{WORDS}

$\begin{array}{ll}\text { bond } & \text { облигации } \\ \text { security } & \text { безопасность, гарантия } \\ \text { elaborate } & \text { тщательно разработанный, подробный } \\ \text { base } & \text { база, основание } \\ \text { invest } & \text { вкладывать, помещать } \\ \text { seller } & \text { продавец } \\ \text { acting } & \text { временно исполняющий обязанности } \\ \text { behalf } & \text { для, ради, в пользу } \\ \text { spread } & \text { распространяться } \\ \text { quote } & \text { цитировать, ссылаться } \\ \text { fraction } & \text { частица } \\ \text { value } & \text { ценность, стоимость, величина } \\ \text { rice } & \text { поднимаются, увеличиваются } \\ \text { original } & \text { первоначальный, подлинный } \\ \text { rate } & \text { норма, расценка, темп, скорость } \\ \text { adjust } & \text { улаживать } \\ \text { yield } & \text { уступать, сдаваться, производство } \\ \text { calculate } & \text { вычислять } \\ \text { determine } & \text { определять, решаться } \\ \text { indicate } & \text { указывать, требовать } \\ \text { amount } & \text { сумма, итог, количество } \\ \text { кuantity } & \text { количество }\end{array}$

\section{Find the answers to the following questions in the text}

1. Where are bonds traded in?

2. What is called «the spread»?

3. Why do most traders use calculators?

4. Why are U.S. government securities the most liquid bonds in the world? 


\section{SKILLS OF NEGOTIATING}

Most negotiations are conducted with a view to reaching a compromise agreement. Both parties together move towards an outcome which is to mutual benefit.

This is a range of tactics which can help conduct negotiations.

It's no use immediately discussing business matters. The topic at the outset of negotiations should be neutral, non-business. It could be immediate experiences, the sort of journey the visitor has had; football, ice-hockey, the morning's newspaper headlines, common interests, etc.

Five per cent of the negotiating time is devoted to breaking the ice. The two parties adjust their thinking and behavior to one another.

If you want to follow the reaction of your visitor introduce in your speech the question «Agree?»

At the very beginning of the talks get agreement covering the purpose, plan, agenda of a meeting.

Here is some advice to a negotiator.

1. First discuss major items, then minor items.

2. Follow the headlines of the plan one by one.

3. Come over to the next point after you have resolved the previous one.

There are always differences of view between the parties.

Here is some advice on problem - solving tactics.

1. Present a problem in general and obtain the other party's view on it.

2. Look together at the possibilities of joint advantage.

3. Suggest practical actions to resolve a problem.

If negotiations are difficult and you are in a deadlock, take time-out. It'll help you build bridges between yourself and your partner when resume negotiations. 


\section{WORDS}

to mutual benefit

agenda

adjust

deadlock

expertise к взаимной выгоде

повестка дня

приспосабливать

тупик, безвыходное положение

опыт

\section{Find the answers to the following questions in the text}

1. What is the purpose of business negotiations?

2. What should be the topics at the outset of negotiations?

3. Why is it important to break the ice?

4. What are the tactics of conducting negotiations?

5. How should parties come out of a deadlock situation?

6. What would you say to your partner at the very first moment of the talks?

7. How would you break the ice if.

a) you see your visitor for the first time?

b) your visitor is your long-standing partner and you know his family and his hobby?

8. What would you say at the close of the talks if

a) you've come to a compromise?

b) you've failed to reach a compromise? 


\section{THE FOUR P'S}

There are four principal controllable factors that provide the most effective choice for the consumer - the Four P's: product, price, place and promotion. The owner of factory manufacturing transportation equipment could produce an economy car, a luxury car, truck, van, tractor, motorcycles and apply different marketing techniques.

Place includes location of production and distribution. The place to see your product could be dealer's showrooms or directly from the factory or from catalogs, direct-mail coupons, even telemarketing with telephone sales people or through computer shopping services.

Promotion includes all forms of marketing communication (advertising, direct mail, customer service, image, special events, sales and the product or service itself). Promotion is the most complex thing-how to select and divide your market according to be type of product, its price and where it will be available. Each group of the population has its own values to which you want to make your product appeal.

The most controllable of these factors is the first «p». - Product (service). All products and services have what have been traditionally called «product life cycles».

The stages of the product life cycle are: introduction, growth, maturity and decline. The length of a product life cycle depends upon the

- intensity of the competition;

- extent to which the new product is an innovation, a modification of an existing product;

- introductory timing of technologically superior products;

- marketing techniques. 


\section{WORDS}

controllable factors

управляемые факторы

promotion

distribution

продвижения товара

marketing communications

распространение распределение

product life cycle

маркетинговые коммуникации

decline

жизненный цикл продукции

спад деловой активности

\section{Find the answers to the following questions in the text}

1. What are the controllable factors in marketing?

2. On what does the pricing policy of a firm depend?

3. What is the product life cycle?

4. What can prolong the product life cycle? 


\section{MARKETING TODAY}

Marketing is a new science. What has been around previously is the art of salesmanship. Salesmanship is the art of manufacturing something and making another person want it. Marketing is the art of finding out what the other person wants, then manufacturing it for him.

In a market of multiple choice, it is no longer sufficient to produce a product and show your customers that it satisfies one of their basic needs. You must show them it provides benefits other products fail to provide, that it can be supplied at a competitive price and above all, supplied reliably. But in this fastchanging world, competitors catch up more quickly than ever.

Preferences that consumers have for this or that product work for shorter and sorter periods. Choice makes marketing work.

Companies need to be constantly engaged in product development, if they wish to grow and make profits. Coca Cola was successful for many years with one product in one size until Pepsi Cola challenged them with a bottle double the size at the same changes. Today Coca Cola has many different soft drinks, cheeses, wines, movie companies, television production companies, to name only a few of its holdings.

Multiple choices for the consumer is the motor that drives the marketing vehicle.

\section{WORDS}

marketing

salesmanship

basic needs

consumer

product development

challenge маркетинг, создание рынков сбыта или спроса

навязывание, проталкивание товара

основные потребности

потребитель

разработка изделия

бросать вызов 
Find the answers to the following questions in the text

1. What is the fundamental difference between salesmanship and marketing?

2. What are the key element of marketing?

3. What is the driving force of marketing?

4. What is the best way to win long-term loyalty to a product? 


\section{COMPUTERS AS TOOLS FOR MARKETING}

Since 1975 the personal computer (PC) has changed the world of business. In the past, the slide ruler, adding machine, the telegraph, the telephone, the hand calculator and the airplane each greatly affected the way business is done. Today the computer has begun to greatly affect the marketing field.

Computer programs are now available for collecting, assessing and analyzing data and even projecting or predicting the future based upon current trends. Some programs have been developed that can simulate potential market conditions so that marketers can pretest strategies. These are mostly experimental but the PC's are today.

With the use of telephone modems, connected to PC's and computer printers and data, base marketers today can assess information about any market, segment of market, even a specific buyer anywhere in the world right from their own office.

Computer software is now available to write data collecting questionnaires, job interview forms, analyze advertising media effectiveness, sales and market trends.

Some US companies in specific marketing areas of consumer goods, forest products, mining products and capital equipment plan for the future up to 50 years by forecasting trends in possible and probable long-term marketing conditions

\section{WORDS}

slide ruler

modem

software

questionnaire

chart логарифмическая линейка

модем

математическое обеспечение

вопросник, анкета, опросный лист

схема, таблица, чертёж 


\section{Find the answers to the following questions in the text}

1. What inventions had a revolutionary effect on business management?

2. Why is PC the most effective tool for marketing now?

3. What computer programmes are now available to assist a manager?

4. Why is it very important for a marketing manager to stimulate potential market conditions?

5. What is the practical application for computer programmes? 


\section{ENGLISH-RUSSIAN DICTIONARY OF ECONOMIC AND BUSINESS TERMS}

accountability

accounting

accounting profit

administered prices

advertising

advertising agencies

advertising medium

affirmative

agent

aggregate demand $(A D)$

aggregate demand curve

aggregate supply (AS)

Americans federation of labor (AFL)

anticipated rate of inflation

antitrust laws

antitrust policy

appreciation bonds

appreciation of a currency

arbitration

asked price

assets

auditing
A

подотчетность

бухгалтерский учет

расчетная прибыль

управляемые или жесткие цены

реклама

рекламные агентства

рекламные средства

упреждающее действие

агент

совокупный спрос

кривая совокупного спроса

совокупное предложение

американская федерация труда (АФТ)

прогнозируемый или ожидаемый уровень

инфляции

антитрестовские законы

антитрестовская политика

облигации с возрастающей стоимостью

повышение курса валюты

арбитраж

цена продавца

активы 


\section{B}

balance of payment

balance of trade

balance sheet

balanced budget

balancing price

bankruptcy

bargaining range

barter

base year

basic economic problems

basis point

benefit reduction rate

bid price

bill auction

bill rate

blue-sky law

board of directors

bond

book-entry form

bookkeeping

bounded rationality

boycott

brand name

branding

break-even price

broad money (m2)

broad span of management

broker

budget deficit

bureaucratization

business cycle платежный баланс

торговый баланс

балансовый отчет

сбалансированный бюджет

равновесная или уравновешивающая цена

банкротство

рамки соглашения

бартер

базовый год

основные экономические проблемы

базисный пункт

норма сокращения в льготах

цена покупателя

аукцион векселей

ставка по векселю

закон «синих небес»

совет директоров

облигация

форма книжной записи

ведение бухгалтерских книг

ограниченная рациональность

бойкот

наименование сорта

обозначение продукта

цена безубыточности

деньги в широком смысле

широкая норма управляемости

брокер

дефицит бюджета

бюрократизация

экономический цикл

English on Economics 
business failure

buyer behavior

buyer's auctions

call option

capital

capital account

capital budgeting

capital deepening

capital gain

capital goods

capital inflows

capital outflows

capital widening

carrying costs

cash management

centralization

certified management accountant

(CMA)

certified public accountant (CPA)

chain of command

change in the income rate to boost

planned expenditure

civilian labor force

civilian unemployment rate

claim

classical model of output

determination

classical unemployment

closed economy

closed 'monopoly

closed shop

coinsurance

English on Economics крах предприятия

поведение покупателя

аукционы покупателей

c

опцион до востребования

капитал

счет движения капитала

анализ эффективности

капиталовложений

углубление капитала

доход от прироста капитала

капитальные товары

приток капитала

отток капитала

расширение капитала

текущие издержки

управление наличными средствами

централизация

дипломированный бухгалтер-аналитик

дипломированный аудитор

система подчиненности

изменение ставки подоходного налога

для подъема планируемых расходов

гражданская рабочая сила уровень

безработицы среди гражданских лиц

требование

классическая модель определения национального объема производства

классическая безработица

закрытая экономика

закрытая монополия

«закрытое» предприятие оговорка

о состраховании 


clause
collateral
collective bargaining
collective goods
collusion
combating monopsony power
combining the current and capital
account demand curves

command economy

commercial bank

commercial paper

commercial puffery

commission broker

committee

commodity money

common stock

compensation

compensation of employees

conditional forecast

conglomerate mergers

congress of industrial organizations (CIO)

consumer choice

consumer goods

consumer price index (CPI)

consumer surplus

consumption schedule

contestable market

continuos process

controlling

convenience goods дополнительное обеспечение

ведение

коллективных договоров

коллективные блага

сговор

борьба с монополией

сочетание кривых спроса на валюту, необходимую как для обеспечения текущих операций, так и для обеспечения движения капитала

командная экономика

коммерческий банк

коммерческие бумаги

коммерческое преувеличение

брокер-комиссионер

комиссия

деньги - товар

обычная акция

компенсация

вознаграждение рабочих и служащих

условный прогноз

конгломератное слияние

конгресс производственных

профсоюзов (КПП)

потребительский выбор

потребительские товары

индекс потребительских цен

прибыль потребителя

график потребления

рынок, способный к конкуренции

последовательный процесс

контроль

товары повседневного спроса 
convenience store

convertible bond

cooperative

corporation

corrective advertising

cost of goods sold

cost-push inflation

costs of inflation

credit union

currency

current account

current account balance

current assets

current liabilities

current ratio

cyclical budget

cyclical deficit

cyclical unemployment

data

dealer

debt

debt-to-equity ratio

demand

demand for money

demand-pull inflation

depository of a currency

derived demand

direct financing

discount store

disposable income (DI)

distribution channel магазин товаров повседневного спроса

конвертируемая облигация

кооператив

корпорация

корректирующая реклама

себестоимость реализованной

продукции

инфляция издержек

издержки от инфляции

кредитный союз

наличные деньги

счет текущих операций

баланс счета текущих операций

текущие активы

текущие пассивы

коэффициент обращения

циклический бюджет

циклический дефицит

безработица

D

данные

дилер

заем

коэффициент задолженности

спрос

спрос на деньги

инфляция спроса

обесценивание валюты

производный спрос

прямое финансирование

магазин, торгующий со скидкой

наличный доход

канал сбыта 
double-entry bookkeeping

durable goods

economic costs of tariffs

economic growth

economic growth with inflation

economic growth with stable prices

effective management

effectiveness

effects of accelerating inflation

effects of an increase in income

effects of an increase in the money supply

effects of deceleration inflation

effects of tariffs and quotas

elasticity

elasticity of demand

elasticity of supply

employment at will

employment-population ratio

entrepreneurship

entitlements

equilibrium in the money market

equilibrium of supply and demand

equity

equity financing

exchange controls

exchange rate

exclusive dealing двойная запись

товары длительного пользования

E

экономические издержки от введения тарифов экономический рост экономический рост, сопровождающийся инфляцией

экономический рост, сопровождающийся стабильным уровнем цен

эффективное управление

эффективность

эффект ускоряющейся инфляции

влияние роста дохода

влияние роста денежного предложения

эффект замедляющейся инфляции

влияние экономического роста на валютный курс

эластичность

эластичность спроса

эластичность предложения

«наем по желанию»

уровень занятости населения

предпринимательство

субсидии

равновесие на денежном рынке

равновесие спроса и предложения

равенство

долевое финансирование"

обменный контроль

валютный курс

ограничение деловых связей 
executive

expansion

expected rate of inflation

expense goods

explicit costs

external debt

factor

final goods and services

finance companies

financial accounting

financial intermediaries

financial markets

first in, first out (FIFO)

first-line managers

fixed costs (FC)

fixed exchange rate

flexibility

flexible interest rates

flextime

floating exchange rate

foreign exchange market

foreign-trade restrictions

fraud

fringe benefits

futures contract

galloping inflation

"Glut» of commodities government account series government budget

government debt

government purchases администратор

подъем

ожидаемый уровень инфляции

расходуемые товары

денежные издержки

внешний долг

F

комиссионер

конечные товары и услуги

финансовые компании

финансовое дело

финансовые посредники

финансовые рынки

«первым прибыл - первым потреблен»

менеджеры первого звена

фиксированные издержки

фиксированный валютный курс

гибкость

гибкая ставка процента

гибкий рабочий график

плавающий валютный курс

валютный рынок

ограничения на иностранную торговлю

мошенничество

дополнительные льготы

срочный контракт

G

галопирующая инфляция

перепроизводство

серии правительственных счетов

правительственный бюджет

правительственный долг 
government securities

grievance

gross national product (GNP)

gross private domestic investment

gross profit

group recession

high-employment budget

high-power incentives

historical cost

house brand

human resources information system (HR1S)

human resources strategy

hybrid business forms

hyperinflation

hypermarket

illegal conduct

implicit costs

income

income before taxes

income statement

income velocity of money

inconvertibility of currency

indexation

individual contributors

individual investor

industrial goods

industrial union

inflation правительственные закупки

ценные правительственные бумаги

жалоба (по трудовым спорам)

валовой национальный продукт?

валовые частные внутренние инвестиции

валовая прибыль

экономический рост, приводящий к спаду

H

бюджет «высокой занятости»

интенсивные стимулы

первоначальная стоимость

марка торгового дома

информационная система трудовых

ресурсов

стратегия в области трудовых ресурсов

смешанные формы бизнеса

гиперинфляция

гипермаркет

I

незаконная деятельность

вмененные издержки

доход

доход от уплаты налогов

отчет о прибылях и убытках

скорость обращения денег

неконвертируемость валюты

индексация

рядовые сотрудники

индивидуальный инвестор

промышленные товары

производственный профсоюз

инфляция 


inflationary recession
informational role of manager
injunction
in-kind transfers
inputs
insurable interest
insurable risk
insurance
insurance company
intermediary
intermediate goods
intermoda! transportation
internal costs
internal debt
internal growth
investment
investment banker
investment encouragement
investment income

job analysis

job description

joint-venture

just in time production

kinked demand curve theory

labour

land

land tax

last in, first out (LIFO)

layoff инфляционный спад

информационная роль менеджера

постановление суда

натуральные трансферты или пособия

затраты

страхуемый интерес

страхуемый риск

страхование

страховая компания

посредник

промежуточные товары

смешанная транспортировка

внутренние издержки

внутренний долг

внутренний рост

инвестиции

инвестиционный банкир

поддержка инвестиций

инвестиционный доход

$\mathrm{J}$

анализ трудовых операций

должностная инструкция

совместное предприятие

производство «точно - в срок»

$\mathbf{K}$

теория изогнутой кривой спрос

L

труд

земельные ресурсы

земельный налог

«последним прибыл - первым потреблен»

временное увольнение

English on Economics 
leading

leakages

legal responsibilities of business

legal restrictions

limit pricing

limited partnership

liquid assets

liquidation

liquidity 1

ong-term debt

macroeconomics

macromarketing

managerial accounting

managing career movement

managing current assents

managing fixed assets

marginal revenue (MR)

marginal revenue product (MRP)

marginal tax rate

market

market economy

market goods

marketable government securities

marketing

marketing nix

market research

marketing research process

marketing strategy

markup percentage руководство

утечки

юридическая ответственность бизнеса

законодательные ограничения

сдерживающее ценообразование

коммандитное товарищество или

ликвидные активы

ликвидация

ликвидность

долгосрочный заем

\section{M}

макроэкономика

макромаркетинг

управленческий учет

управление продвижением по служебной лестнице

управление текущими активами

управление фиксированными активами

предельный доход

предельный денежный продукт

предельная доля налога

рынок

рыночная экономика

рыночные блага

рыночные правительственные ценные бумаги

маркетинг

маркетинговый комплекс

маркетинговые исследования

процесс маркетинговых исследований

маркетинговая стратегия

процент наценки 
mediation

mentor

merchandise balance

merchant

merchantilism

microeconomics

micromarketing

middle managers

middleman

minimum standard of living

mixed economy

moderate inflation

money demand curve

money market deposit account

money market fund

money market mutual fund shares

money supply

monitoring

moral hazard

mortgage

motivation

municipal bonds

mutual adjustment

mutual insurance company

mutual savings bank

national debt

national income (N1)

national product

natural level of unemployment

natural resources посредничество

наставник

товарный баланс

торговец

меркантилизм

микроэкономика

микромаркетинг

менеджеры среднего звена

комиссионер

минимальный уровень жизни

смешанная экономика

умеренная инфляция

кривая спроса на деньги

депозитный счет денежного рынка

фонд денежного рынка

акции инвестиционных фондов открытого

предложение денег

Наблюдение

моральный риск

ипотека

мотивация

муниципальные облигации

взаимопомощь

взаимный

компания взаимного страхования

сберегательный банк

$\mathbf{N}$

государственный долг

национальный доход

национальный продукт

естественный уровень безработицы

природные ресурсы 
negative income tax

net capital inflows

net capital outflows

net economic welfare (NEW)

net export

net imports

net income

net national product (NNP)

net saves

net taxes

net worth

nominal

nominal aggregate demand

nominal exchange rate

nominal interest rate

nondurable goods

non-for-profit firm

normal profit

objective product

off-price retailing

open economy

open market operation

open monopoly

operating income

operation target

opportunity costs of capital

option

order processing

ordinary stock

output негативный подоходный налог чистый

приток капитала

чистый отток капитала

чистое экономическое благосостояние

чистый экспорт

чистый импорт

чистый доход

чистый национальный продукт

чистый объем продаж

чистые налоги

собственный капитал

номинальный

номинальный совокупный спрос

номинальный валютный курс

номинальная процентная ставка

товары кратковременного пользования

некоммерческая организация

нормальная прибыль

$O$

объективный продукт

распродажа

открытая экономика

операции на открытом рынке

открытая монополия

доход от основной деятельности

операционная задача

альтернативные издержки капитала

опцион

обработка заказа

обычная акция

объём производства 
over-the-counter market

overtime standard

packaging and material handling

paradox of thrift

paradox of value

partnership

patents

payoff matrix

pension fund

perfect competition

performance appraisal

personal consumption expenditure

personal income (pi)

personal risk

personal selling

planned-expenditure schedule

planned-investment schedule

planning

planning a distribution strategy

planning a product strategy

plant location

positive reinforcemen

potential output

poverty - level

predatory pricing

premium

price

price ceilings

price discrimination рынок незарегистрированных ценных бумаг

сверхурочный стандарт

$\mathbf{P}$

упаковка и перемещение внутри хранилища

парадокс бережливости

парадокс стоимости

Партнерство

патенты

платежная матрица

пенсионный фонд

совершенная конкуренция

оценка результатов деятельности

личные потребительские расходы

личный доход'

личный риск

индивидуальная продажа

график планируемых расходов

график планируемых инвестиций

планирование

планирование стратегии сбыта

планирование продуктовой стратегии

размещение производства

поощрение

потенциальный объем производства

уровень бедности

грабительское ценообразованияе

премия

цена

установление потолка цен

ценовая дискриминация 
price fixing

price index

price level

price stability

pricing methods

primary advertising

primary securities market

private accountant

private goods

private - purpose municipal bonds

process design

process of human resources

management

process of management

producer price index

production

profit

promotion

promotional strategy

public accountant

public debt

public goods

public relations

public service advertising

pure economic profit

pure economic rent

pure risk

push

quality

quality assurance фиксированные цены

индекс цен

уровень цен

стабильность цен

методы ценообразования

первичная реклама

первичный рынок ценных бумаг

бухгалтер

индивидуальные блага

целевые облигации

проектирование процесса производства

процесс управления трудовыми

ресурсами

процесс менеджмента

индекс цен производителей

производство

прибыль

стимулирование сбыта, продвижение

стратегия стимулирования сбыта

аудитор

государственный долг

общественные блага

общественные связи

реклама общественных служб

чистая экономическая прибыль

чистая экономическая рента

чистый риск

«проталкивание» (товара или услуги)

\section{Q}

качество

гарантия качества 


\section{$\mathrm{R}$}

raising standard wage rate

rate ofinflation quality

rate of return

rate of return on capital

rate of turnover

real exchange rate

real interest rate

realized expenditure

regulation

rental

required reserves

reservation price

reserves

responsibilities of business

retail price maintenance

retailing

retained earning

return on assets (ROA)

revenue

rigid prices

rigid wage

risk

risk aversion

risk management

risk neutrality

risk pooling

sales branch sales office

sales promotion saving schedule

savings

savings bonds увеличение ставки заработной платы

уровень инфляции

норма прибыли

норма прибыли на капитал

норма оборота

реальный валютный курс

реальная процентная ставка

осуществленные расходы

регулирование

арендная плата

резервные требования

стартовая цена

резервы

ответственность бизнеса

поддержание розничных цен

розничная продажа

нераспределенная прибыль

доход на активы

доход

жесткие или управляемые цены

жесткая заработная плата

риск

отвращение риска

управление риском

нейтральность риском

группировка риска

$S$

торговое отделение

отдел сбыта

стимулирование продаж

график сбережений

English on Economics 


\begin{tabular}{|c|c|}
\hline savings deposits & сбережения \\
\hline savings function & сберегательные облигации \\
\hline scrambled merchandising & сберегательные вклады \\
\hline sealed-bid auction & функция сбережения \\
\hline secondary securities market & закрытый аукцион \\
\hline secured debt & вторичный рынок ценных бумаг \\
\hline secured short-term debt & гарантированный заём \\
\hline securities & гарантированный краткосрочный заём \\
\hline selection & ценные бумаги \\
\hline self-insurance & отбор \\
\hline self-service store & самострахование \\
\hline separation & магазин самообслуживания \\
\hline services & расторжение договора \\
\hline shareholder & услуги \\
\hline shopping goods & пайщик \\
\hline short- and long-run adjustments & товары предварительного выбора \\
\hline shortage & кратко - и долгосрочное регулирование \\
\hline short-run & дефицит \\
\hline short-term debt & краткосрочный период \\
\hline skill of managers & краткосрочный заём \\
\hline small business & способности менеджера \\
\hline social insurance & малый бизнес \\
\hline solvency & социальное страхование \\
\hline speculation & платежеспособность \\
\hline speculative income & спекуляция \\
\hline speculative risk & спекулятивный доход \\
\hline staffing & спекулятивный риск \\
\hline stock exchange & формирование штата \\
\hline stockbroker & биржевый брокер или биржевый маклер \\
\hline stockholder & акционер \\
\hline strategic planning & стратегическое планирование \\
\hline
\end{tabular}




\begin{tabular}{|c|c|}
\hline strategy of penetration & широко известные товары \\
\hline strike & забастовка \\
\hline structural budget & структурный бюджет \\
\hline structural deficit & структурный дефицит \\
\hline structural unemployment subsidiary & структурная безработица \\
\hline subsistence wages & дочернее предприятие \\
\hline subsidization & заработная плата, определяемая \\
\hline supervisory managers & минимумом средств существования \\
\hline supply & субсидирование \\
\hline supply curve (SS) & контролеры \\
\hline surplus & предложение \\
\hline target market & целевой рынок \\
\hline target pricing & целевое ценообразование \\
\hline tariff & тариф \\
\hline technical analysis & технический анализ \\
\hline tender offer & предложение о скупке пакета акций \\
\hline term insurance & страхование на срок \\
\hline termination & окончательное увольнение \\
\hline thrift & сберегательная касса \\
\hline time deposits & срочные вклады \\
\hline time preference & временное предпочтение \\
\hline total profit & общая прибыль \\
\hline total revenue & общий доход \\
\hline total unemployment rate & общий уровень безработицы \\
\hline trade credit & торговый кредит \\
\hline trademark & торговая марка \\
\hline transaction deposit & вклад на текущий счет \\
\hline transaction money (M1) & деньги для сделок \\
\hline transfer & перевод \\
\hline transmission of information & передача информации \\
\hline transportation & транспортировка \\
\hline
\end{tabular}




\begin{tabular}{|c|c|}
\hline treasure bills & казначейские векселя \\
\hline treasure bonds & казначейские облигации \\
\hline \multirow[t]{2}{*}{ treasure notes } & среднесрочные казначейские облигации \\
\hline & $\mathbf{U}$ \\
\hline underemployed & неполностью занятый \\
\hline underlying rate of inflation & основной уровень инфляции \\
\hline underwriting & подписка \\
\hline undistributed profits & нераспределенная прибыль \\
\hline unemployed & безработный \\
\hline unemployment rate & уровень безработицы \\
\hline unity of command & единство власти \\
\hline unsecured debt & негарантированный заём \\
\hline unsecured short - term debt & негарантированные краткосрочные займы \\
\hline used of funds & использование фондов \\
\hline \multirow[t]{2}{*}{ utility } & полезность \\
\hline & V \\
\hline value added & добавленная стоимость \\
\hline venture capital market & рынок капитала с повышенной степенью \\
\hline vertical marketing system & вертикальная маркетинговая система \\
\hline vertical mergers & вертикальное слияние \\
\hline vertical price fixing & вертикальные фиксированные цены \\
\hline \multirow[t]{2}{*}{ voluntary unemployment } & добровольная безработица \\
\hline & W \\
\hline warehousing & складирование \\
\hline warranty & гарантия \\
\hline wealth & богатство \\
\hline whole fife insurance & пожизненное страхование \\
\hline wholesaling & оптовая продажа \\
\hline working capital & оборотный капитал \\
\hline
\end{tabular}




\section{ЛИТЕРАТУРА}

1. Англо-русский словарь по экономике и бизнесу / отв. ред. Т.А. Мамедова. Ростов н/Д: Феникс, 1997.

2. Богацкий, И.С. Бизнес-курс английского языка / И.С. Богацкий, Н.М. Дюканова; под общ. ред. И.С. Богацкий. - 5-е изд., испр. - Киев: Логос, 2003. - 352 с.

3. Воронцова, И.И. Английский язык для студентов экономических факультетов: учеб. пособие / И.И. Воронцова, А.К. Ильина, Ю.В. Момджи. - М.: ПРИОР, 1999. - 144 c.

4. Коваленко, П.И. Английский для экономистов / П.И. Коваленко, И.А. Агабекян. Ростов н/Д: Феникс, 1999. - 352 с.

5. Любимцева, С.Н. Деловой английский для начинающих: учебник / С.Н. Любимцева, Б.М. Тарковская. - 2-е изд., перераб. и доп. - М.: Высш. шк., 1995. - 367

c.

6. Сальникова, Л.В. Английский язык для менеджеров / Л.В. Сальникова. - NBПРЕСС. - М., 1992.

7. Ститт-Годэс, В. Деловой английский - быстро / В. Ститг-Годэс. - Ростов н/Д: Феникс, 1996. - 576 с.

8. Шевелева, C.A. English on Economics: учеб. пособие для вузов / С.А. Шевелева. - М.: ЮНИТИ, 2001. - 375 с.

9. Джю Долан, Э. Economics. Англо-русский словарь-справочник / Б. Домненко. - М., 1994.

10. Samuelson, P.A. Economics / P.A. Samuelson, D.W. Nordhaus - Fourteenth ed. McGraw-Hill, INC, 1992.

11. An outline of the American Economy / R.L. McCan, - M. Perlman, W.H. Peterson, S. English on Economics 
Ramsey. - USIA, 1981,1984,1991.

12. Ashworth, W. A short history of the international economy since 1850 / W. Ashworth. fourth ed. - Longman, 1987.

13. Samuelson, W.F. Managerial economics / W.F. Samuelson, S.G. Marks. - Second ed. The Dryden Press, 1995. 


\author{
Читао Ирина Айтечевна \\ Хатхе Асиет Асланбечевна \\ Хабекирова Зарема Схатбиевна \\ Калашаова Аза Аскеровна
}

\title{
English on Economics
}

\author{
Методические указания \\ по работе с экономическими текстами \\ на английском языке
}

\section{(для студентов экономических языков)}

ООО «Электронные издательские технологии»

385020, Республика Адыгея, г. Майкоп, а/я 09

elit-publishing@yandex.ru

1,9 Мб

Подписано к использованию 24.02.2016 г. 